\title{
IMPLEMENTASI PERENCANAAN TATA RUANG KOTA TANJUNGBALAI (STUDI DI KANTOR BAPPEDA KOTA TANJUNGBALAI)
}

\author{
Tengku Aryanda ${ }^{1)}$, Irda Pratiwi ${ }^{2)}$ \\ ${ }^{1)}$ Fakultas Hukum Universitas Asahan \\ ${ }^{2)}$ Fakultas Hukum Universitas Asahan \\ email: ${ }^{1,}$ irdapratiwi1986@ gmail.com ${ }^{2)}$
}

\begin{abstract}
ABSTRAK
Wilayah teritorial Negara Kesatuan Republik Indonesia yang merupakan negara kepulauan bercirikan kepulauan, baik sebagai satu kesatuan yang menghamparkan ruang darat, wilayah laut, dan ruang udara, yang meliputi wilayah di dalam bumi, serta sumber daya, Penting sekali untuk memperkuat upaya penyelenggaraannya secara arif, efisien, dan bermutu dengan berpedoman pada prinsip-prinsip penataan ruang sehingga kualitas wilayah wilayah negara yang bermutu tinggi dapat dipertahankan secara berkelanjutan untuk terwujudnya kesejahteraan dan kesejahteraan masyarakat. keadilan sosial sesuai dengan landasan konstitusional Undang-Undang Dasar Negara Republik Indonesia Tahun 1945.
\end{abstract}

Kata kunci: Implementasi, Perencanaan, Tata, Ruang, Kota Tanjungbalai.

\section{ABSTRACT}

The territorial territory of the Unitary State of the Republic of Indonesia which is an archipelagic country characterized by archipelago, either as a single unit that spreads land space, sea area and air space, which includes areas within the earth, as well as resources. and with quality guided by the principles of spatial planning so that the quality of the territory of the country with high quality can be maintained in a sustainable manner for the realization of public welfare and welfare. social justice in accordance with the constitutional foundation of the 1945 Constitution of the Republic of Indonesia.

Keywords: Implementation, Planning, Layout, Spatial, Tanjungbalai City. 
Volume 22 No. 1, FEBRUARI 2021 ISSN 2686-5750 (ONLINE)

ISSN 1411-0717 (CETAK)

\section{PENDAHULUAN}

Indonesia adalah dengan wilayah kedaulatan yang membentang dari Sabang sampai Merauke dengan jumlah penduduk yang terus bertambah setiap tahun. Oleh karena itu dulu dibentuk pemerintahan di segala bidang di setiap daerah untuk menyesuaikan dan melayani penduduknya, mulai dari pemerintah pusat hingga pemerintah daerah. "Negara Indonesia di sebut "eenheidstaat" maka Indonesia tidak akan mempunyai daerah dalam lingkungannya yang bersifat "staat" juga. Daerah Indonesia akan dibagi dalam daerah yang lebih kecil.

Wilayah teritorial Negara Kesatuan Republik Indonesia yang merupakan negara kepulauan bercirikan kepulauan, baik sebagai satu kesatuan yang menghamparkan ruang darat, wilayah laut, dan ruang udara, yang meliputi wilayah di dalam bumi, serta sumber daya, Penting sekali untuk memperkuat upaya penyelenggaraannya secara arif, efisien, dan bermutu dengan berpedoman pada prinsip-prinsip penataan ruang sehingga kualitas wilayah wilayah negara yang bermutu tinggi dapat dipertahankan secara berkelanjutan untuk terwujudnya kesejahteraan dan kesejahteraan masyarakat. keadilan sosial sesuai dengan landasan konstitusional Undang-Undang Dasar Negara Republik Indonesia Tahun 1945.

Negara Kesatuan yang disusun dan dipersiapkan sesuai dengan konsep dan sistem kemampuan sentralisasi yang kewenangan untuk mengubah dan mengurus urusan pemerintahan (pemerintahan terpusat tunggal) atau oleh pusat secara bersama-sama dengan organnya tersebar di daerah. Sentralisasi yang disertai dengan cara pemisahan organ-organ yang menjalankan sebagian kewenangan pemerintah pusat di daerah dikenal dengan istilah dekonsentrasi (Centralisatie met deconcentralisatie). ${ }^{1}$

Prinsip otonomi daerah yang dilaksanakan oleh pemerintah daerah tidak hanya sampai pada pemerintah provinsi dan kabupaten / kota, tetapi juga berlaku untuk tingkat kecamatan dan kecamatan. Hal ini dimaksudkan agar kewenangan atau kebijakan yang dibentuk dan disalurkan dari pusat juga dapat dirasakan oleh manusia di kelurahan tersebut.

Kecamatan sebagai unsur pokok di daerah berperan penting dalam melaksanakan gagasan otonomi daerah yang diberikan oleh pemerintah pusat kepada pemerintah daerah. Hubungan antara pemerintah pusat dan otoritas lingkungan harus dijaga sedemikian rupa sehingga standar tersebut dapat dipertahankan dan diterapkan sepenuhnya. ${ }^{2}$

$$
\text { Sejak dikeluarkannya }
$$

Undang-Undang Nomor 32 Tahun 2004 tentang Pemerintahan Daerah, maka sekarang Undang-Undang tersebut telah mengalami perubahan dengan Undang-Undang Nomor 23 Tahun 2014 tentang Pemerintahan Daerah, sehingga penyelenggaraan otonomi daerah yang sesuai dengan Undang-Undang juga mengalami perubahan yang sangat besar. "Secara lebih operasional Undang-Undang Otonomi Daerah mengamanahkan, bahwa penyelenggaraan pemerintah diarahkan untuk memberi

${ }^{1}$ I Gede Pantja Astawa, Problematika Hukum Otonomi Daerah Di Indonesia (Bandung: Alumni, 2013). hlm, 26. Irawansoejito, Hubungan Pemerintah Pusat Dan Pemerintah Daerah, (Jakarta: Rineka Cipta, 1990). hlm, 186. 
Volume 22 No. 1, FEBRUARI 2021 ISSN 2686-5750 (ONLINE)

ISSN 1411-0717 (CETAK)

kewenangan yang lebih luas kepada Pemerintah Daerah dengan maksud untuk lebih meningkatkan pelayanan dan partisipasi masyarakat terhadap pelaksanaan pembangunan di segala bidang". 3

Pada intinya, ia terus menggunakan ajaran otonomi seluasluasnya dalam arti bahwa daerah diberi kewenangan untuk memanipulasi dan menyesuaikan semua faktor kewenangan di luar Pemerintah Pusat. Daerah mempunyai kewenangan membuat kebijakan daerah untuk memberikan pelayanan, memperbesar partisipasi, memprovokasi dan memberdayakan manusia yang bertujuan untuk meningkatkan kesejahteraan rakyat. Sejalan dengan prinsip-prinsip tersebut maka diterapkan pula sila tentang otonomi yang aktual dan bertanggung jawab. ${ }^{4}$

Pada dasarnya, pembangunan berkelanjutan berangkat dari satu tujuan mulia, khususnya untuk memperoleh kehidupan yang lebih memuaskan bagi semua, untuk saat ini, hari berikutnya dan untuk generasi yang akan datang. Dalam pelaksanaan pembangunan di seluruh negeri, terlihat jelas bahwa dalam perbaikannya akan dihadapkan pada tantangan kerusakan lingkungan yang sangat besar, yang pengaruhnya mulai dirasakan oleh lingkungan sekitar saat ini. Sehingga pemerintah kota harus melakukan upaya dalam hal ini.

3 Melva Fitri Sialagan, Ismail, and Zaid Afif, "Analisis Hukum Tentang Penataan Desa Sebagai Wujud Efektivitas Penyelengaraan Pemerintah Desa Dilihat Dari Undang-Undang Desa," Jurnal Pionir LPPM Universitas Asahan 6, no. 1 (2020): 25-30.

${ }^{4}$ Ibid.
Adanya ruang terbatas dan pemahaman masyarakat yang berkembang akan pentingnya penataan ruang, oleh karena itu sangat penting untuk menata asosiasi ruang yang transparan, efektif, dan partisipatif guna mewujudkan ruang yang aman, nyaman, produktif, dan berkelanjutan. Bahwa secara geografis Negara Kesatuan Republik Indonesia berada pada lokasi yang rawan bencana sehingga diperlukan penataan ruang yang berbasis mitigasi bencana sebagai upaya untuk meningkatkan perlindungan dan pemulihan keberadaan dan mata pencaharian.

Pemerintah kota dalam upaya mewujudkan penataan ruang wilayah perlu berpijak pada kajian lingkungan strategis ini, harus peka terhadap berbagai masalah sosial yang dihadapi dalam penataan lingkungan perumahan. Manusia sudah sedikit banyak berhasil mengatur kebiasaannya sendiri dan kini dituntut untuk mengupayakan teknik normal pengaturan alam dan lingkungan agar senantiasa seimbang, khususnya yang berkaitan dengan tanah, air dan udara. Tanah adalah objek yang dicari manusia tetapi hanya sedikit dipahami.

Berdasarkan Pasal 11 ayat (1) Undang-Undang Nomor 26 Tahun 2007 tentang Penataan Ruang, diketahui bahwa kewenangan pemerintah kabupaten / kota dalam penataan ruang meliputi: 1 . Pengaturan, pembinaan, dan pengawasan pelaksanaan penataan ruang kabupaten / kota dan kawasan strategis kabupaten / kota; 2. Melaksanakan penataan ruang kabupaten / kota; 3. Pelaksanaan penataan ruang kawasan strategis kabupaten / kota metropolitan; dan 
Volume 22 No. 1, FEBRUARI 2021 ISSN 2686-5750 (ONLINE)

ISSN 1411-0717 (CETAK)

Kerjasama penataan ruang antar kabupaten / kota. ${ }^{5}$

Perencanaan sektoral jaringan prasarana publik atau penyuluh menjadi sasaran Bappeda Tanjungbalai dalam mewujudkan kawasan perkotaan yang berwawasan lingkungan. Kota metropolitan yang berwawasan lingkungan berkapasitas kota yang bersih dari pencemaran udara, tertib dan memiliki keindahan alam kayu di sekitar jalan-jalan utama di kawasan kota sehingga mampu menciptakan kemegahan panorama kota. Dengan mengembangkan wilayah perkotaan yang dituju, diperlukan perencanaan yang matang.

$$
\text { Rencana Pembangunan }
$$

Daerah Tanjungbalai diatur dalam Peraturan Daerah Kota Tanjungbalai Nomor 2 Tahun 2013 tentang Rencana Tata Ruang Wilayah Kota Tanjungbalai 2013-2033 yang bertujuan untuk memahami Kota Tanjungbalai sebagai kota metropolis di tepi sungai dengan alternatif dan pelayanan serta regional. industri skala yang religius, nyaman, aman, produktif dan berkelanjutan.

Bentuk suatu perencanaan terhadap pembangunan di kota Tanjungbalai Badan disain persenan suatu Kota Tanjungbalai. Salah satunya tentang peningkatan Tata Ruang Kota Tanjungbalai yang disinergikan dengan visi dan misi Pemerintah Kota Tanjungbalai dalam rangka meningkatkan kesejahteraan masyarakat. $^{6}$

Berdasarkan uraian latar belakang di atas maka penulis

5 Undang-Undang Nomor 26 Tahun 2007 Tentang Penataan Ruang, n.d.

${ }^{6 " H t t p s: / / B a p p e d a . T a n j u n g b a l a i k o t a . G ~}$ o.Id/WpContent/Uploads/2017/10/RTRWtb.P df, Diakses Pada Tanggal 28 Juli 2020 Pada Pukul. 14.00 WIB." melakukan penelitian yang dituangkan dalam bentuk skripsi dengan judul : "Implementasi Perencanaan Tata Ruang Kota Tanjungbalai (Studi di Kantor Bappeda Kota Tanjungbalai)”.

\section{METODE PENELITIAN}

Metode di dalam penelitian ini adalah mengunakan metode dengan pendekatan empiris, yaitu melighat suatu keadaan permasalahan dari fakta-fakta yang terjadi dilapangan. Kemudian data-data tersebut dikumpulkan sebagai bahan untuk mencawab setiap masalah yang diangkat dalam penelitian ini. Dengan mengunakan metode empiris maka capaian yang ingin dilakukan dalam menemukan suatu kebenaran ilmiah.

Jenis Penelitian Didalam menjalankan pendekatan yuridis empiris ini, Dengan menggunakan metode deduktif bisa menggambarkan ketentuan-ketentuan mengenai Implementasi Perencanaan Tata Ruang Kota Tanjungbalai (Studi di Kantor Bappeda Kota Tanjungbalai). Sedangkan metode induktif ialah data yang diperoleh dari hasil penelitian dilapangan demi diambil kesimpulan yang bersifat umum.

Lokasi penelitian dilakukan di kota Tanjungbalai, yakni pada Kantor Bappeda Tanjung Balai, dipilihnya kantor Bappeda Tanjung Balai ini mengingat objek penelitian yang hendak dilakukan berkenaan dengan Implementasi Perencanaan Tata Ruang Kota Tanjungbalai (Studi di Kantor Bappeda Kota Tanjungbalai), sehingga dengan demikian sungguh memudahkan peneliti demi mendapatkan informasi atau data yang berhubungan dengan Implementasi Perencanaan Tata 
Volume 22 No. 1, FEBRUARI 2021 ISSN 2686-5750 (ONLINE) ISSN 1411-0717 (CETAK)

Ruang Kota Tanjungbalai (Studi di Kantor Bappeda Kota Tanjungbalai).

Sumber Data Penulis dalam melakukan penelitian untuk mengabil data penelitian menggunakan sumber data, dimana sumber data yang digunakan di penelitian ini didapat dari sumber data primer dan sumber data sekunder. Dengan menggunakan dua macam bahan hukum yang meliputi Sumber data primer yaitu sumber data yang diperoleh secara langsung dari sumber pertama yang terkait dengan permasalahan yang akan dibahas. Sumber data yang diperoleh dari lapangan dengan wawancara berbagai pihak yang menyangkut terhadap permasalahan dalam penelitian.

Sumber data sekunder yaitu bahan hukum yang diperoleh Buku sebagai salah satu bahan hukum merupakan berbagai buku yang berkaitan dengan pembahasan penelitian yang dilakuan oleh penulis mengenai bahan hukum yang terdiri dari: a. Merupakan hasil dari bahan pustaka ataupun dari literatur buku; b. Bahan yang berasal dari berbagai hasil seminar dan tulisan artikel yang ada di internet sebagai bahan hukum yang berhubungan dengan penelitian serta pembahasan dalam penulisan skripsi ini. c. Selanjutnya mengambil dari berbagai bahan hukum dari hasil yang dilakukan penelitian sebelumnya.

Teknik pengumpul data hendak sungguh menentukan hasil penelitian sehingga apa yang menjadikan tujuan penelitian ini bisa tercapai. Demi mendapatkan hasil penelitian yang objektif dan bisa dibuktikan kebenaranya serta bisa di pertanggungjawabkan hasilnya, sehingga didalam kebenarannya serta dan dipertanggungjawabkan hasilnya, sehingga didalam penelitian ini hendak di pergunakan alat pengumpul data.

Didalam memporelah data yang diperlukan, sehingga dilakukan wawancara terhadap responden yang dilakukan secara langsung ialah dengan Bappeda Kota Tanjung Balai terkait Implementasi Perencanaan Tata Ruang Kota Tanjungbalai (Studi di Kantor Bappeda Kota Tanjungbalai).

Analisis data kualitatif dilakukan apabila data empiris yang diperoleh ialah data kualitatif berupa kumpulan berwujud kata-kata dan tidak rangkaian angka serta tidak bisa disusun didalam kategorikategori/struktur klasifikasi. Data bisa saja dikumpulkan didalam aneka macam cara (observasi, wawancara, intisari dokumen, pita rekaman) dan biasanya diproses terlebih dahulu sebelum siap digunakan (melalui pencatatan, pengetikan, penyuntingan, atau alih-tulis), tetapi analisis kualitatif tetap menggunakan katakata yang biasanya disusun ke didalam teks yang diperluas, dan tidak menggunakan perhitungan matematis atau statistika sebagai alat bantu analisis.

\section{HASIL DAN PEMBAHASAN Implementasi Perencanaan Tata Ruang Kota di Kota Tanjungbalai}

Pelaksanaan yang mengacu pada pembangunan infrastruktur bidang Permukiman yang menitikberatkan pada pembangunan permukiman dan penataan bangunan dan lingkungan Hidup. Khusus yang berkaitan dengan permukiman, perencanaan dilakukan dengan mengkaji kriteria kesiapan pelaksanaan kegiatan untuk 
Volume 22 No. 1, FEBRUARI 2021 ISSN 2686-5750 (ONLINE) ISSN 1411-0717 (CETAK)

merumuskan aplikasi dan hal-hal yang ingin dilakukan dalam perbaikan kontrak sesuai dengan masalah strategis yang berdampak padanya. ${ }^{7}$

Bappeda Kota Tanjungbalai dalam mengimplementasikan membutuhkan peran serta lingkungan dalam mendukung penataan ruang kota yang lebih tinggi. Yaitu menumbuhkan partisipasi lingkungan dengan cara melakukan pelestarian penjangkauan untuk setiap Kecamatan di Kota Tanjungbalai terkait dengan Tujuan Penataan Ruang Kota Tanjungbalai dengan tujuan "Mewujudkan Kota Tanjungbalai sebagai kota metropolis di tepi sungai dengan perdagangan dan persembahan serta industri skala regional yang religius, nyaman, aman, produktif dan berkelanjutan ".

Alur kebijakan dan cakupan kegiatan focal point pemenuhan keinginan permukiman atau hunian yang dilengkapi sarana dan prasarana penolong bagi seluruh masyarakat untuk terus meningkat, sehingga ketentuan tersebut memotivasi pengakuan kota tanpa permukiman kumuh.

Hal-hal yang perlu dilakukan dan menjadi tantangan adalah sebagai pengikut: $^{8}$ a. Perumusan kebijakan teknis dan teknik kontrak pembangunan di perkotaan dan pedesaan; b. Bimbingan teknis, supervisi teknis dan fasilitasi pengembangan kawasan permukiman baru di kawasan kota dan pengembangan kawasan perdesaan yang memungkinkan; c. Bimbingan teknis, supervisi teknis dan fasilitasi untuk memperbaiki permukiman kumuh terbaik, yang meliputi

\footnotetext{
${ }^{7}$ Ibid.

${ }^{8}$ Ibid.
}

peremajaan kawasan dan pembangunan rumah susun sederhana; d. Bimbingan teknis, pembinaan teknis dan fasilitasi perbaikan permukiman di daerah tertinggal, terpencil, perbatasan dan pulau-pulau kecil, serta penanggulangan bencana jamu dan keresahan sosial; e. Penyusunan norma, standar, metode dan kriteria, serta peningkatan kelembagaan dan peran serta masyarakat di bidang pengembangan kontrak;

Bappeda Kota Tanjungbalai bekerja sama dengan semua sektor dalam melaksanakan. Dalam hal ini, terdapat beberapa pusat lingkungan hidup yang tumbuh menjadi prioritas, yaitu: ${ }^{9}$ a. Pusat Lingkungan pertama ditetapkan sebagai pendidikan utama dan menengah, perubahan dan layanan, terletak di Kelurahan Pantai Johor di Kecamatan Datuk Bandar; b. Pusat Lingkungan 2d berbeda sebagai yang terpenting dan pendidikan menengah, kesehatan, pemerintahan, perumahan menengah dan rendah, yang terletak di Desa Pahang di Kecamatan Datuk Bandar; c. Pusat Lingkungan $1 / 3$ dibedakan menjadi pendidikan besar dan menengah, kesehatan, perdagangan dan jasa, permukiman menengah dan rendah, yang terletak di Kelurahan Gading di Kecamatan Datuk Bandar; d. Pusat Lingkungan keempat unik seperti pendidikan penting dan menengah, pemerintahan, perumahan menengah dan rendah, alternatif dan layanan yang terletak di Desa Selat Tanjung Medandi, Kecamatan Datuk Bandar Timur; e. Pusat Lingkungan Kelima dipastikan sebagai pemukiman padat dan sedang, pemerintahan, kesehatan, pelatihan utama dan menengah 
Volume 22 No. 1, FEBRUARI 2021 ISSN 2686-5750 (ONLINE) ISSN 1411-0717 (CETAK)

ditempatkan di Desa Pulau Simardan di Kecamatan Datuk Bandar Timur; f. Pusat Lingkungan keenam yaitu kesehatan, pendidikan dasar dan menengah, pemerintahan, alternatif dan pelayanan yang ditempatkan di Desa Muara Sentosa di Kecamatan Sei Tualang Raso; Pusat Lingkungan ketujuh tepatnya sebutan untuk industri, pemerintah, sekolah menengah dan perguruan tinggi yang ditempatkan di Desa Sei Raja di Kecamatan Sei Tualang Raso; Kedelapan Pusat Lingkungan Hidup seperti kesehatan, perdagangan dan jasa, peruntukan industri, pemerintahan, pendidikan dasar dan menengah yang terletak di Kelurahan Beting Kuala Kapias di Kabupaten Teluk Nibung; dan Pusat Lingkungan Kesembilan khususnya sebagai pendidikan paling penting dan menengah, kesehatan, pemerintahan, perumahan menengah dan rendah terletak di Kecamatan Pematang Pasir di Kabupaten Teluk Nibung.

Sebagaimana diungkapkan dengan bantuan Sufri Eka Dharma mengatakan bahwa: "Peran Bappeda Kota Tanjungbalai sangat diperlukan dalam pelaksanaan Penataan Ruang Kota di Kota Tanjungbalai sesuai dengan Peraturan Daerah Kota Tanjungbalai Nomor 2 Tahun 2013 tentang Rencana Tata Ruang Wilayah Kota Tanjungbalai Tahun 20132033". 10 "Bappeda Kota Tanjungbalai dalam pengawasan tata ruang masih berpegang pada regulasi dan regulasi yang ada. Sebagaimana halnya Bappeda Kota Tanjungbalai dalam menjalankan fungsinya membutuhkan

10 Wawancara Sufri Eka Dharma Subbid Perencanaan Infrastruktur Dan Kewilayahan Bappeda Kota Tanjung Balai, Pada Tanggal 27 Oktober 2020 Hari Selasa Pada Pukul 10.00 WIB., n.d. kerjasama dengan instansi lain. Koordinasi Bappeda Kota Tanjungbalai dengan bisnis yang berbeda akan sangat membantu Bappeda Kota Tanjungbalai dalam Rencana Tata Ruang Kota di Kota Tanjungbalai ". 11

Sehubungan dengan sanksi pada Pasal 108, ayat (4) telah diatur, yaitu: "setiap perencanaan tata ruang yang melakukan konstruksi fisik kecuali memiliki izin konstruksi akan menjadi tantangan untuk dihukum. " Untuk memperoleh izin mendirikan bangunan, perangkat lunak diserahkan secara tertulis kepada pemerintah daerah. Perubahan izin bangunan gedung yang sudah disetujui harus diminta kembali secara tertulis kepada pemerintah daerah. Utilitas izin mendirikan bangunan ditolak jika sudah tidak sesuai lagi dengan ciri bangunannya,

\section{Faktor-faktor yang dapat Mendukung dan Menghambat Implementasi Perencanaan Tata Ruang di Kota Tanjungbalai}

Faktor Pendukung Dalam pengesahan, terdapat cukup banyak faktor pendukung untuk optimalisasi yaitu: ${ }^{12} 1$. Adanya kebijakan otonomi daerah (desentralisasi). Bappeda Tanjungbalai memerlukan koordinasi dengan instansi lain, misalnya dalam pengelolaan perumahan atau kontrak pembangunan yaitu Perumahan Rakyat dan Kawasan Permukiman Kota Tanjungbalai, serta sulitnya konversi lahan pertanian, khususnya Dinas Pertanian Kota Tanjungbalai. Kantor untuk mendapatkan tujuan yang disengaja. Jika Bappeda Kota Tanjungbalai mendapat bantuan dari instansi lain, maka perencanaan
${ }^{11}$ Ibid.

12 Ibid. 
Volume 22 No. 1, FEBRUARI 2021 ISSN 2686-5750 (ONLINE)

ISSN 1411-0717 (CETAK)

perbaikan di Kota Tanjungbalai akan berjalan maksimal. "Seiring dengan adanya suatu prinsip penyelenggaraan otonomi daerah, maka harus berorientasi pada peningkatan kesejahteraan masyarakat dengan selalu memperhatikan kepentingan dan aspirasi yang tumbuh dalam masyarakat". ${ }^{13}$

Partisipasi masyarakat dalam perencanaan pembangunan. Partisipasi masyarakat dalam kebijakan asuransi pembangunan di negara-negara yang menerapkan demokrasi, termasuk di Indonesia, bukanlah hal baru. Partisipasi masyarakat merupakan proses teknis untuk memberikan kesempatan dan kewenangan yang lebih luas kepada masyarakat secara kolektif untuk menyelesaikan berbagai masalah. Sebagai konsep atau praktik perbaikan, konsep partisipasi pernah hanya disebut di tahun 60-an ketika cukup banyak kelompok internasional yang mempromosikan partisipasi dalam perencanaan, pelaksanaan, dan praktik penilaian pembangunan, pentingnya masyarakat dalam perbaikan desa adalah mengingat masyarakat lokal yang mengakui lebih lanjut tentang sejumlah masalah seperti pembangunan. infrastruktur dan infrastruktur desa, pengembangan potensi moneter terdekat. "Rencana Kerja Pemerintah Daerah (RKPD) Kota Tanjung Balai dalam memuat rancangan kerangka ekonomi daerah, prioritas pembangunan daerah, serta rencana kerja dan pendanaan untuk jangka waktu selama 1 (satu) tahun

13 Zaid Afif Sunarti, Abdul Gani, "Penyelenggaraan Pemerintah Kecamatan Ditinjau Dari Uu No. 23 Tahun 2014 Tentang Pemerintah Daerah," Jurnal Pionir LPPM Universitas Asahan Vol. 5 N0.4 JuliDesember 2019 5, no. 23 (2019): 343-348. yang disusun dengan berpedoman kepada Rencana Kerja Pemerintah (RKP) dan program strategis nasional yang ditetapkan oleh Pemerintah Pusat". ${ }^{14}$

Landasan hukum dari suatu penyelenggaraan partisipasi rukun tetangga disebutkan dalam UUD 1945 yang menyatakan bahwa partisipasi adalah hak dasar warga negara, dan partisipasi politik merupakan sila dasar demokrasi. Pentingnya peningkatan tujuan partisipasi untuk meningkatkan kesejahteraan lingkungan dan kehidupan manusia kelas satu, pengentasan kemiskinan melalui pemenuhan kebutuhan dasar, pembangunan sarana dan prasarana, peningkatan potensi keuangan daerah, serta pemanfaatan sumber daya alam dan lingkungan yang berkelanjutan. Partisipasi masyarakat memiliki banyak bentuk, mulai dari partisipasi masyarakat secara langsung. dalam aplikasi otoritas atau dalam sifat miring seperti sumbangan dana, energi, pemikiran, pendapat atau bahkan penolakan terhadap pembuatan liputan otoritas. sejauh ini, Bantuan masyarakat sebagaimana dimaksud dalam Pasal 127 terdapat hak masyarakat yaitu: a. mengetahui rencana tata ruang; $b$. menikmati nilai perkenalan rumah sebagai hasil dari penataan ruang; $\mathrm{c}$. mendapatkan kompensasi yang wajar atas kerugian yang timbul dari pelaksanaan kegiatan pembangunan sesuai dengan rencana tata ruang; $d$. mengajukan keberatan kepada instansi yang berwenang terhadap sifat yang tidak sesuai dengan format

14 Junindra Martua Khairul Amri Panjaitan, Bahmid, "Efektivitas Implementasi Peraturan Walikota Tanjungbalai," Jurnal Tectum, Universitas Asahan. 1, no. 2 (2020): 212-224. 
Volume 22 No. 1, FEBRUARI 2021 ISSN 2686-5750 (ONLINE)

ISSN 1411-0717 (CETAK)

spasial di wilayahnya; e. mengajukan kebutuhan tambahan izin dan penghentian pembangunan yang sekarang tidak sesuai dengan rencana tata ruang kepada pejabat yang berwenang; dan mengajukan gugatan ganti rugi kepada pemerintah dan / atau pemegang izin apabila hal-hal yang akan dilakukan pembangunan yang tidak sesuai dengan tata ruang menimbulkan kerugian.

Faktor Penghambat Dalam melaksanakan, tentunya juga terdapat kendala-kendala yang harus diatasi, terdapat berbagai unsur penghambat dalam yaitu Bisnis perumahan semakin berkembang. Kota metropolitan Tanjungbalai merupakan kawasan yang sangat strategis yang menghadirkan kemungkinan yang luar biasa bagi para pebisnis perumahan untuk meningkatkan usahanya. Lokasi metropolis yang strategis merupakan lokasi tempat yang diutamakan dalam penataan ruang karena memiliki pengaruh yang sangat vital dalam lingkup Kota Tanjungbalai terhadap perekonomian, sosial, subkultur dan / atau lingkungan. "Jika lokasi strategis ini dimanfaatkan oleh pengembang perusahaan komersial residensial, kawasan itu akan mengalami penurunan di semua sektor penataan ruang di Kota Tanjungbalai". ${ }^{15}$

\section{Kurangnya Kesadaran}

Masyarakat Akan Kewajibannya Suatu undang-undang akan terlaksana secara optimal jika semua elemen memiliki ciri yang sesuai sehingga tercipta keteraturan dan keamanan dalam masyarakat. melalui perusahaan seperti perusahaan perumahan atau usaha perumahan toko (ruko). Perlunya ketersediaan

${ }^{15}$ Ibid. akses layanan yang tersedia demi terwujudnya suatu penegakkan hukum dan kepastian hukum pada masyarakat. Diciptakannya suatu aturan hukum bertujuan memberikan suatu kepastian hukum bagi masyarakat dengan memegang teguh asas keadilan secara merata. Terciptanya suatu tatanan baru pada kehidupan masyarakat demi terwujudnya pembaharuan masyarakat dengan menjaga nilainilai sosial yang mengatur pergaulan hidup masyarakat. Ada begitu sedikit kesenangan tentang bertanya-tanya tentang capaian yang akan datang tentu menghadapi tantangan pada masa yang akan datang.

Tidak perlu dilakukan pembatasan akan pemenuhan harapan masyarakat demi kebaikan bersama. Perlunya dilakukan suatu pembaharuan dengan selalu berinovasi terhadap berbagai perubahan yang ditujukan kepada masyarakat tersebut. Saling memiliki sikap untuk menjaga setiap kepemilikan hak dan kewajiban seseorang dengan berpegang teguh terhadap hukum. Memiliki suatu keyakinan dan pemahaman secara mendalam konsisten dalam menentukan suatu sikap yang teguh dan mandiri. Perlunya ketersediaan pelayanan sarana dan prasarana dalam menunjang pergerakan serta layanan kepada masyarakat dalam meningkatkan akses terhadap masyarakat dalam menikmati segala bentuk fasilitas umum tata ruang kota.

Ketersediaan layanan fasilitas tersebut akan memberikan ruang gerak bagi masyarakat dalam mengakses setiap kegiatan di dalam kehidupan masyarakat. Dengan perencanaan yang matang serta ketersediaan fasilitas sarana dan 
Volume 22 No. 1, FEBRUARI 2021 ISSN 2686-5750 (ONLINE)

ISSN 1411-0717 (CETAK)

prasarana masyarakat akan dimudahkan dalam melaksanakan suatu aktivitas ataupun kegiatan. Bila akses fasilitas yang tersedia mengalami suatu kekurangan tentu hal ini akan berdampak buruk bagi masyarakat maupun penegak hukum dalam menjalankan. Penyebab sketsa penggunaan lahan itu sendiri bertujuan untuk mengatur penyediaan, peruntukan, penggunaan lahan sehingga memberikan manfaat yang berkelanjutan, optimal, serasi, seimbang. Ciri penting dari perencanaan tata guna lahan tidak semata-mata sebagai sistem penyediaan lahan, tetapi juga sebagai jalur penatagunaan lahan sesaat dan jangka panjang yang harus dilakukan terkait dengan rencana pembangunan pemerintah.

Penyebab Penyusunan

Rencana Penggunaan Lahan adalah sebagai berikut Tergunanya suatu lahan secara merata sesuai dengan peruntukan dan pemanfaatan terhadap masyarakat. Berdasarkan kenyataan bahwa tanah merupakan obyek perencanaan, seringkali berbagai hak telah dilampirkan. Dilakukannya suatu alokasi dari ketersediaan lahan yang ada untuk memberikan ruang akses bagi masyarakat. Masyarakat tidak terlepas dari akses tanah dimana tanah sebagai suatu tempat bagi masyarakat dalam hidup dan bertempat tinggal. Penyelenggara, penyuluhan mengenai penentuan suatu tata guna lahan yang dilakukan oleh pemerintah dalam mengelola serta menata setiap pertanahan. Dengan mengunakan rancangan penggunaan lahan yang baik dan maksimal sehingga terwujudnya suatu tata kota yang sesuai dengan aturan hukum. Perlunya penataan wilayah suatu ruang dengan memenuhi suatu pedoman dalam tata guna suatu tanah demi terwujudnya suatu kepastian hukum dalam kepemilikan suatu lahan dengan berpedoman pada suatu aturan hukum.

\section{KESIMPULAN}

Berdasarkan hasil penelitian yang dilaksanakan di Badan Perencanaan Pembangunan Daerah (Bappeda) Kota Tanjungbalai sesuai dengan rumusan masalah, maka dapat ditarik kesimpulan sebagai berikut Pelaksanaan, yang mengacu pada peningkatan infrastruktur di kawasan Permukiman yang berfokus pada pembangunan permukiman dan penataan bangunan. dan lingkungan. Bappeda Kota Tanjungbalai dalam memberlakukan menuntut partisipasi lingkungan dalam mendukung penataan ruang kota yang lebih tinggi. Yaitu meningkatkan partisipasi masyarakat melalui penjangkauan ke setiap Kecamatan di Kota Tanjungbalai dengan melibatkan Tujuan Penataan Ruang Kota Tanjungbalai dengan tujuan "

Dalam menegakkan, tentunya terdapat pula hambatan-hambatan yang harus diatasi, terdapat cukup banyak faktor penghambat di yaitu: a. Usaha perumahan yang, sehingga kawasan tersebut akan mengalami penurunan di semua bidang penataan ruang di Kota Tanjungbalai. b. Kurangnya kesadaran publik tentang kewajiban mereka. Suatu aturan akan terlaksana secara optimal jika semua elemen menonjolkan keakuratannya sehingga tercipta keteraturan dan perlindungan dalam masyarakat. Tanah untuk pendapatannya sendiri tanpa memperhatikan keseimbangan lingkungan.

Mempunyai kedudukan yang sangat penting dalam perencanaan 
Volume 22 No. 1, FEBRUARI 2021 ISSN 2686-5750 (ONLINE)

ISSN 1411-0717 (CETAK)

dan pelaksanaan penataan ruang di Kota Tanjungbalai, sehingga saat ini tidak merubah karakteristik wilayah tata ruang yang direncanakan, diharapkan kedepannya Bappeda Tanjungbalai Kota dapat lebih mengoptimalkan tanggung jawab dan fungsinya.

Lingkungan harus mampu berperan aktif memberikan bantuan dalam mengawasi penanganan masalah konversi lahan dalam mewujudkan rencana tata ruang Kota Tanjungbalai yang benar. Partisipasi masyarakat dalam pelaksanaan program perbaikan merupakan salah satu struktur tantangan masyarakat bagi penyelenggaraan pembangunan. Partisipasi masyarakat juga merupakan salah satu elemen yang mempengaruhi berhasil tidaknya suatu perbaikan perangkat lunak di suatu daerah. Partisipasi masyarakat diperlukan karena paket kewenangan yang diterapkan tidak ada bedanya dengan masyarakat. Lingkungan perlu menjadi bagian dari kebersamaan dengan pihak berwenang untuk berperan dalam meningkatkan dan memfasilitasi pelaksanaan program pembangunan.

\section{DAFTAR PUSTAKA \\ Buku}

I Gede Pantja Astawa. Problematika Hukum

Otonomi Daerah Di Indonesia. Bandung: Alumni, 2013.

Irawansoejito.

Hubungan

Pemerintah Pusat Dan

Pemerintah Daerah,.

Jakarta: Rineka Cipta, 1990.

Khairul Amri Panjaitan, Bahmid,

Junindra

Martua.

"Efektivitas

Implementasi

Peraturan

Walikota
Tanjungbalai.'

Jurnal

Tectum, Universitas Asahan. 1, no. 2 (2020): 212-224.

Sialagan, Melva Fitri, Ismail, and Zaid Afif. "Analisis Hukum

Tentang Penataan Desa Sebagai Wujud Efektivitas Penyelengaraan Pemerintah Desa Dilihat Dari UndangUndang Desa." Jurnal Pionir LPPM Universitas Asahan 6, no. 1 (2020): 25-30.

Sunarti, Abdul Gani, Zaid Afif. "Penyelenggaraan

Pemerintah Kecamatan Ditinjau Dari Uu No. 23 Tahun $2014 \quad$ Tentang Pemerintah Daerah.” Jurnal Pionir LPPM Universitas Asahan Vol. 5 N0.4 JuliDesember 2019 5, no. 23 (2019): 343-348.

"Https://Bappeda.Tanjungbalaikot a.Go.Id/WpContent/Uploads/2017/10/R TRWtb.Pdf, Diakses Pada Tanggal 28 Juli 2020 Pada Pukul. 14.00 WIB.'

Undang-Undang Nomor 26 Tahun 2007 Tentang Penataan Ruang, n.d.

Wawancara Sufri Eka Dharma Subbid Perencanaan Infrastruktur Dan Kewilayahan Bappeda Kota Tanjung Balai, Pada Tanggal 27 Oktober 2020 Hari Selasa Pada Pukul 10.00 WIB., n.d. 